\title{
Generalized Lichen Nitidus in a boy with Niemann-Pick disease type $B^{*}$
}

\section{Líquen nítido generalizado em paciente com doença de Niemann-Pick tipo B}

\author{
Vera Barreto Teixeira ${ }^{1}$
}

\author{
Inês Coutinho ${ }^{1}$
}

José Carlos Cardoso²

Óscar Tellhechea ${ }^{3}$

\begin{abstract}
Generalized lichen nitidus is an uncommon chronic inflammatory dermatosis with very characteristic histological findings. Its pathogenesis is still unclear; very rarely it has been associated with genetic disorders. Herein we report the case of a 12-year-old boy with Niemann-Pick disease who developed generalized lichen nitidus.
\end{abstract}

Keywords: Granuloma; Lichen nitidus; Niemann-Pick disease, type B

Resumo: Líquen nítido generalizado é uma dermatose inflamatória crônica, rara, com achados histológicos muito característicos. Sua patogênese não está completamente esclarecida e, muito raramente, tem sido associado a doenças genéticas. Reportamos o caso de um doente do sexo masculino, de 12 anos de idade, com Doença de Niemann-Pick, que desenvolveu líquen nítido generalizado.

Palavras-chave: Doença de Niemann-Pick tipo B; Granuloma; Líquen nítido

\section{INTRODUCTION}

First described by Pinkus in 1901, lichen nitidus (LN) is an uncommon disorder that affects children and young adults. It typically presents with multiple glistening, flesh-coloured, pinhead-sized, domeshaped papules usually limited to the genitalia, upper extremities and abdomen. Although usually asymptomatic, it may occasionally be pruritic. Its pathogenesis remains unclear, although it is typically not associated with any systemic manifestations.

\section{CASE REPORT}

A 12-year-old boy presented with a 12-month history of asymptomatic papules that first appeared on his shoulders and gradually spread to involve most of the skin surface. The patient had Niemann-Pick disease type B, confirmed by genetic study at the age of 4 . Hepatosplenomegaly and dyslipidaemia were the main manifestations of the disease. He has been in the 10th percentile for both weight and height. His neurological state and intellec- tual ability were normal. There was no history of consanguinity between his parents. His 16 year-old sister was also affected by Niemann-Pick disease, although without any cutaneous manifestations.

On physical examination, there were numerous discrete, skin-coloured, flat-topped, monomorphic, pinhead-sized papules grouped over the abdomen, umbilicus, trunk, penile shaft, upper extremities, knees and malleolar regions. On the lower back some of the lesions were grouped in linear array, possibly as a result of the Koebner phenomenon (Figure 1). The face, oral mucosa and palmoplantar surfaces were not involved.

Histopathological examination revealed a well circumscribed, lymphohistiocytic granulomatous infiltrate in the papillary dermis. This infiltrate appeared to be clutched by elongated epidermal ridges resembling a "ball and claw" pattern (Figure 2). The clinicopathological picture was entirely in-keeping with lichen nitidus.

\footnotetext{
Received on 29.05.2013.

Approved by the Advisory Board and accepted for publication on 16.06.2013.

* Work performed at the Dermatology Department, Hospitals of the University of Coimbra (HUC) - Coimbra, Portugal.

Financial Support: none

Conflict of Interests: none

M.D. - MD - Dermatology Resident at the Dermatology Department, Hospitals of the University of Coimbra (HUC) - Coimbra, Portugal.

MD - Hospital Assistant, Dermatology Department, Hospitals of the University of Coimbra (HUC) - Coimbra, Portugal.

MD, PhD, Professor - Head of Service, Dermatology Department, Hospitals of the University of Coimbra (HUC) - Coimbra, Portugal. 


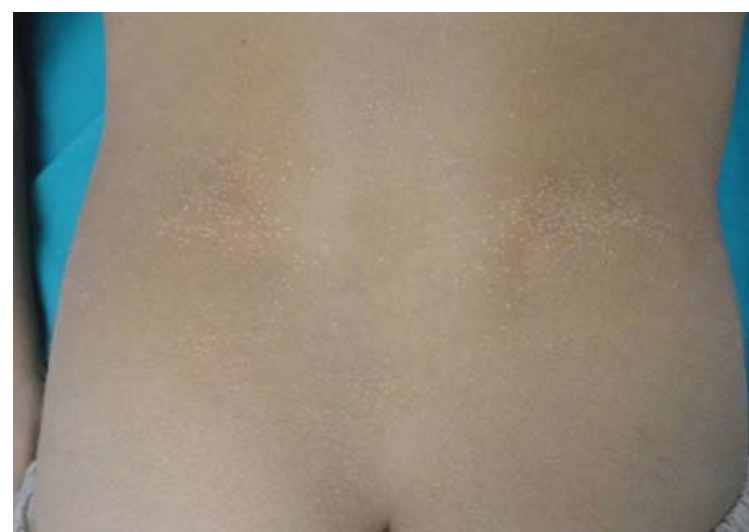

FIGURE 1: Numerous flesh-colored, flat papules on the lower back. Note the linear array of some lesions

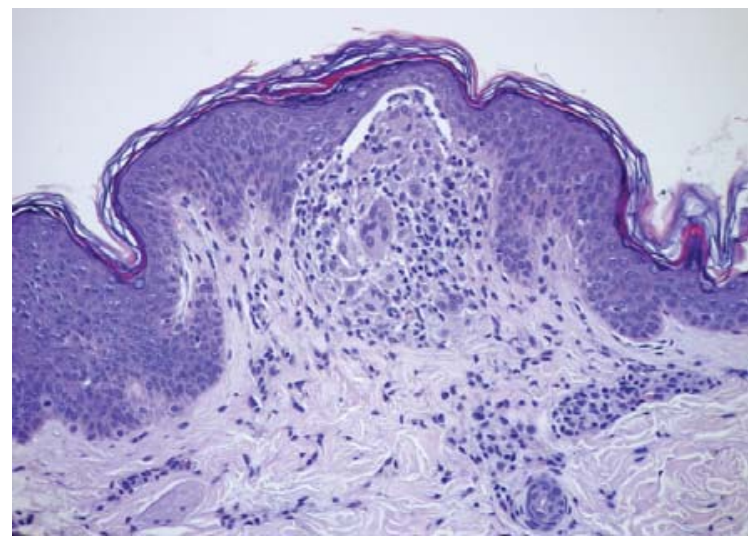

FIGURE 2: Light microscopy of a papule shows the focal well-circumscribed lymphohistiocytic infiltrate in the dermal papilla and the lateral rete ridges surrounding the infiltrate in a "ball in claw" picture

\section{DISCUSSION}

Rarely, LN may be generalized as in our patient. Its clinical course is unpredictable, although spontaneous resolution can occur after several years. ${ }^{1}$ Generalized LN has occasionally been reported in association with genetic disorders: Down syndrome (four cases) ${ }^{2}$ and Russell-Silver syndrome (one case). ${ }^{3}$ No causative link was found between these associations. Further studies are needed to clarify if this association is merely coincidental, since Down syndrome is quite common in the general population.

Our patient has Niemann-Pick disease, a rare autosomal recessive lysosomal storage disorder. There are three major subtypes (A, B and C), depending on the gene locus defect. NP types A and B both are caused by deficiency of acid sphingomyelinase, resulting in accumulation of sphingomyelin in multiple organs. Subtype B is rarer and less severe than type A, with longer survival, sometimes until adulthood. Hepatosplenomegaly is the main manifestation in this type.

Skin manifestations reported in Niemann-Pick disease are rare, and most consist of non-specific lesions such as xanthomas, eruptive xanthomatous lesions due to hyperlipidaemia, juvenile xanthogranuloma, café-au-lait macules and pruritic lesions. ${ }^{4}$ Specific skin lesions in NP have seldom been reported, with ultrastructural detection of lysosomal bodies within phagocytic cells, typical of the disease. ${ }^{4}$

To our knowledge, this is the first report of generalized lichen nitidus in Niemann-Pick disease. More cases and possibly further studies will be needed to clarify whether this association found in our patient is only coincidental or if it has any pathogenetic significance.

\section{REFERENCES}

1. Chen W, Schramm M, Zouboulis CC. Generalized lichen nitidus. J Am Acad Dermatol. 1997;36:630-1.

2. Botelho LF, Magalhães JP, Ogawa MM, Enokihara MM, Cestari Sda C. Generalized Lichen nitidus associated with Down's syndrome: case report. An Bras Dermatol. 2012;87:466-8

3. Kanai C, Terao M, Tanemura A, Miyoshi Y, Ozono K, Katayama I. Generalized lichen nitidus in Russell-Silver syndrome. Pediatr Dermatol. 2013;30:150-1.

4. Toussaint M, Worret WI, Drosner M, Marquardt KH. Specific skin lesions in a patient with Niemann-Pick disease. Br J Dermatol. 1994;131:895-7.

\author{
MAILING ADDRESS: \\ Vera Barreto Teixeira \\ Praceta Mota Pinto \\ 3000-075 - Coimbra \\ Portugal \\ E-mail: vera.teixeira.derm@gmail.com
}

How to cite this article: Teixeira VB, Coutinho I, Cardoso JC, Tellechea O. Generalized Lichen Nitidus in a boy with Niemann-Pick disease type B. An Bras Dermatol. 2013;88(6)977-8. 